\title{
Seismic Assessment in a Historical Masonry Minaret by Linear and Non-linear Seismic Analyses
}

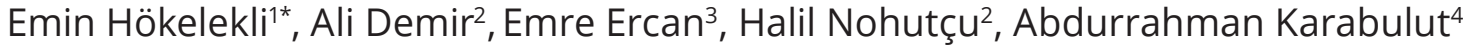 \\ 1 Department of Civil Engineering, Bartın University, Kutlubey Yazicilar Campus, 74110 Bartın Merkez/Bartın, Turkey \\ 2 Department of Civil Engineering, Celal Bayar University, Şehit Prof. Dr. İlhan Varank Campus, 45140 Yunusemre/Manisa, Turkey \\ ${ }^{3}$ Department of Civil Engineering, Ege University, Erzene, Ege University Rectorate, Genclik Cad. No: 12, 35040 Bornova/izmir, Turkey \\ ${ }^{4}$ Department of Mechanical Engineering, Afyon Kocatepe University, Erenler, Gazlıgöl Road Rectorate E Block, 03200 \\ Afyonkarahisar Merkez/Afyonkarahisar, Turkey \\ * Corresponding author, e-mail: ehokelekli@bartin.edu.tr
}

Received: 17 October 2019, Accepted: 25 February 2020, Published online: 23 March 2020

\begin{abstract}
Operational Modal Analysis (OMA) method is frequently used in order to determine dynamical properties of historical masonry structures. In this study, damage pattern of historical Alaca minaret which is selected as application is investigated under different ground motions by updating finite element models (FEM) depending on operational modal analysis test. Initial Finite element model was prepared in ABAQUS V10 program and numerical dynamic characteristics of minaret were determined. In addition, experimental dynamic properties of minaret were provided by operational modal analysis. Initial numerical model of brick masonry structure was calibrated via OMA method. Then, linear and non-linear seismic analyses of calibrated FEM of historical minaret were performed by using different earthquakes acceleration records that occurred in Turkey. Concrete Damage Plasticity model was taken into account in non-linear seismic analyses. As a result of the analyses, it is concluded that the stresses obtained with linear analyses aren't as realistic as the non-linear analyses results and the earthquakes can cause some damages in the minaret.
\end{abstract}

Keywords

brick masonry minaret, operational modal analysis, ambient vibration testing, damage estimation, concrete damage plasticity model

\section{Introduction}

Historical structures such as mosque, minaret, tower, castle etc. reflect general properties of nations in terms of architectural and structural characters. Historical masonry structures represent the architectural features of the period and the country in which they were built. Historical masonry minarets which are slender and tall structures are frequently built by using mortar, stone or clay brick. The seismic behaviors of historic structures don't resemble each other because local materials and local construction methods are used in their building. Minarets have a winding stairs system made of wood or stone [1].

Numerical and experimental works on historical masonry minarets have been made by many researchers in terms of both structural and architectural [2-9] temperature variations, etc. Gentile and Saisi [10] investigated the seismic safety of the Monza church tower by using operational modal analysis method and updated numerical FEM of the tower. Dogangün et al. [11] investigated the seismic behaviors of three historical masonry minarets having different heights under two ground motions recorded during the 1999 Kocaeli and Düzce earthquakes. Foti et al. [12] investigated a tower in Bari, Italy. As a result of analyses, it was observed that experimental results were in compliance with FE results. Oliveira et al. [13] performed in situ operational modal analysis tests of historical minarets with different sizes and updated the FE models. Diaferio et al. [14] investigated the dynamic parameters of historical bell tower of Cathedral of Trani by means of nondestructive methods such as OMA and ground penetrating radar tests. Finally, it was asserted that a model reflecting actual structure was developed. Cakir and Uysal [15] numerically determined effect of walls on the seismic performance of the Erzurum clock tower. Bartoli et al. [16] calibrated the FEM of a masonry towers via OMA method and ambient vibration tests. The Enhanced Frequency Domain Decomposition (EFDD)/Frequency Domain Decomposition (FDD) and 
the data driven Stochastic Subspace Identification (SSI) techniques are frequently used for the determination of dynamic properties of historical structures $[9,17,18]$. Demir et al. [19] determined the effects of FEM calibrated on structural behavior of historical Sultan mosque in Manisa, Turkey. Calibrated and non-calibrated FE models were subjected to earthquakes and determined damage state of historical structure. Nohutcu et al. [20] investigated seismic damage and the collapse mechanism of the historical stone masonry minaret. Linear and nonlinear time history seismic analyses were carried out on the calibrated FEM. The analyses showed that the results of the nonlinear analyses were quite realistic when compared with existing damage. Altunışık et al. [21] calibrated FEM of a masonry bastion by using OMA method and manual and automated model calibrating. The maximum differences are reduced from 27 to $3 \%$ by using manual calibrating method and to $0.02 \%$ with automated model calibrating method. Nohutcu et al. [22] investigated damage situation of historical brick İmaret mosque under different earthquakes.

This study presents a detailed investigation of seismic damage situation of historical Alaca minaret by using FE model calibrated with OMA method. Experimental dynamic characteristics of the structure were accomplished via OMA method and FE analyses. Seismic analyses of calibrated FE model subjected to were carried out with linear and non-linear seismic analyses. Seismic damage propagation patterns of the brick masonry minaret were obtained for both earthquake ground motions.

\section{Structural properties of Alaca minaret}

\subsection{History of the minaret}

Alaca minaret is located in Bolvadin which is one of the oldest locations in Anatolia. Bolvadin is historic-rich as the reign of the Seljuk's and Ottoman empires took a long time. The city was designed with different historical structures such as mosques and minarets, fountains, inns, aqueducts, bridges during. Minarets usually constitute of 8 parts. Their parts are named as base, pulpit, transition segment, cylindrical body, balcony, upper part of minaret body, spire. The Alaca Mosque and minaret, which was built in $1271 \mathrm{AD}$, has remained standing until present day. Upper parts of pulpit and pulpit were made of clay brick and stone materials, respectively. The height of the minaret is $27 \mathrm{~m}$, the pulpit has $3 \mathrm{~m} \times 3 \mathrm{~m}$ square section and the cylindrical body has a diameter of $2.15 \mathrm{~m}$. The photographs of minaret are presented in Fig. 1.
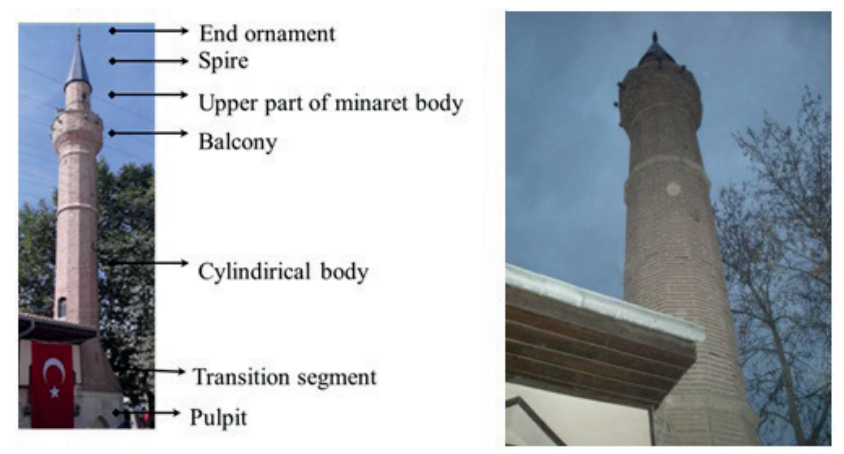

Fig. 1 Minaret of Alaca mosque

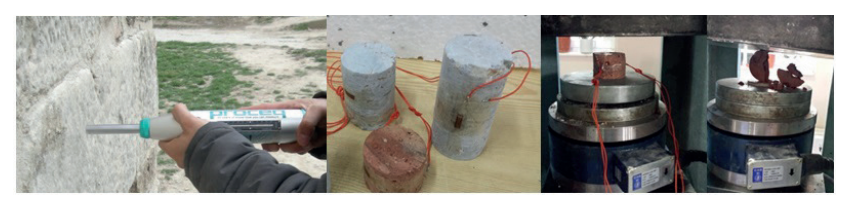

Fig. 2 Material tests

\subsection{Material properties}

Material properties used the initial finite element method were obtained by nondestructive Schmidt hammer, ultrasonic pulse velocity, porosity, density tests and destructive uniaxial compression and Brazilian tests (Fig. 2) as explained in literature [22].

Material parameters of the masonry brick walls were determined by formulations given in the literature [19, 22]. Material parameters of masonry brick walls of minaret are presented in Table 1.

Finite element model of the masonry minaret were set up by using Abaqus V10 [23] software (Fig. 3). Convergence analysis was performed in order to the most suitable mesh size by using the FE model of the minaret. Initial mesh size was determined as $0.25 \mathrm{~m}$ in accordance with the convergence analysis. Modal analyses were carried out for each range of the mesh given in Table 2 and the convergence graphic is showed in Fig. 4.

According to the convergence analysis results in Table 2, the most suitable mesh size was selected as 0.25 m. A total of 61107 four-node tetrahedral (C3D4) solid elements and 19809 nodes were used for the initial FE model.

Table 1 Initial material parameters of masonry walls

\begin{tabular}{|c|c|c|c|c|c|}
\hline Materials & 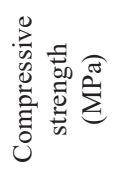 & 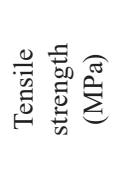 & 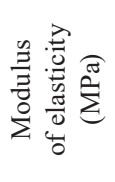 & 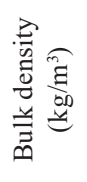 & 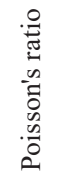 \\
\hline Stone masonry & 7.42 & 0.74 & 4400 & 2200 & 0.17 \\
\hline Brick masonry & 4.21 & 0.421 & 1300 & 1750 & 0.17 \\
\hline
\end{tabular}




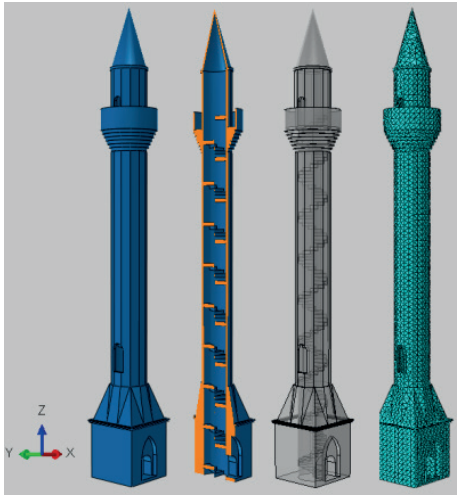

Fig. 3 3D solid model and FE model of minaret

Table 2 Mesh sizes convergence

\begin{tabular}{lcc}
\hline Mesh size $(\mathrm{m})$ & $\begin{array}{c}\text { The first natural } \\
\text { frequency }(\mathrm{Hz})\end{array}$ & $\begin{array}{c}\text { Number of } \\
\text { elements }\end{array}$ \\
\hline 0.65 & 0.682 & 10199 \\
0.45 & 0.627 & 13685 \\
0.55 & 0.605 & 15337 \\
0.35 & 0.584 & 31226 \\
0.25 & 0.582 & 61107 \\
\hline
\end{tabular}

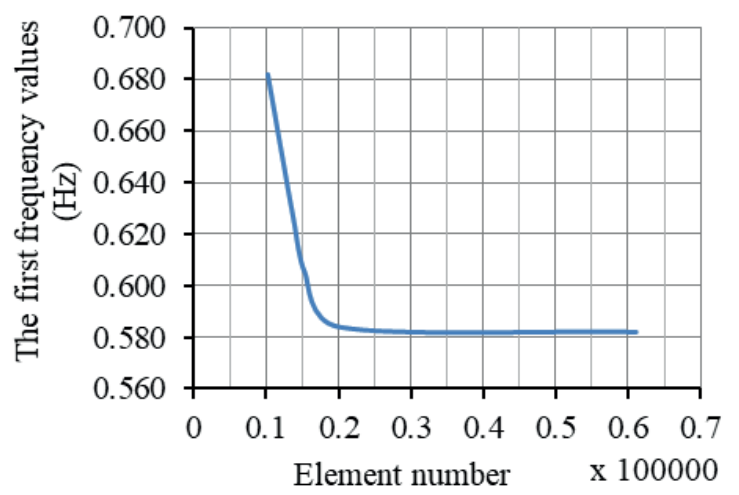

Fig. 4 Frequency and mesh size relationship

The modal analysis was performed and the mode shapes and numerical frequency values of the minaret are presented in Fig. 5. It is seen that first mode shape occurs in $\mathrm{x}$ direction and second mode shape occurs in $\mathrm{y}$ direction.

\section{Modal identification from Ambient Vibration Data}

OMA which is used for modal identification is an experimental method depended on environmental vibration. The locations on minaret of the accelerometers were determined by using the mode shapes of the minaret. A total of 12 uni-axial accelerometers were placed as indicated in Fig. 6. Vibrations caused by the environmental effects such as wind, traffic, etc. were collected by accelerometers and data storage units.

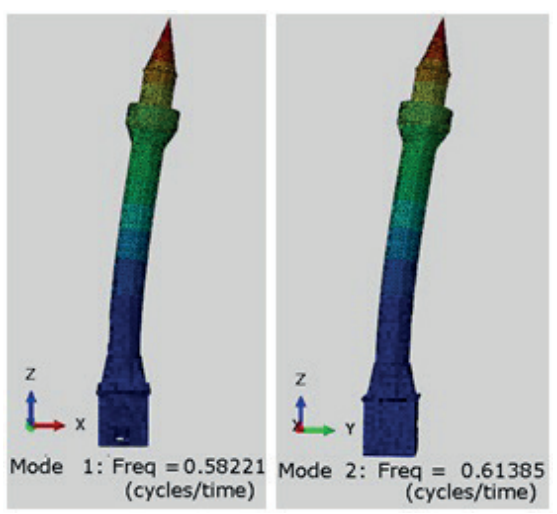

Fig. 5 The first and second mode shapes and frequency values from the initial FE model

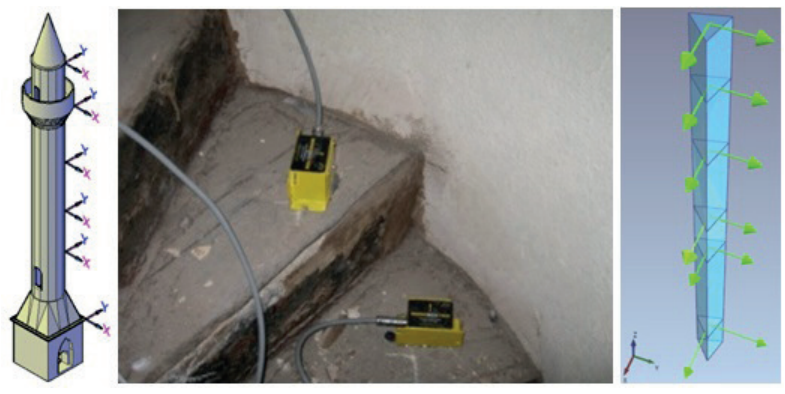

Fig. 6 Locations and directions of the accelerometers on the minaret

Accelerations data acquired from ambient vibration tests were uploaded to the ARTeMIS [24] program and modal identification of the minaret were determined by using the Stochastic Subspace Identification (SSI) Method [25, 26]. SSI technique is the most well-known and used parametric time domain estimators. Stabilization diagram acquired from the SSI technique and the experimental frequency value are given in Fig. 7 and Table 3, respectively.

Numerical and experimental frequencies are comparatively presented in Table 4 . The calibrated FE model of the minaret is attained by altering in elasticity modulus of brick masonry walls. Before calibrating, differences between numerical and experimental frequencies of first and second modes were $52 \%$ and $50 \%$, respectively. Modulus of elasticity of brick masonry wall increases from $1300 \mathrm{MPa}$ to $4400 \mathrm{MPa}$. Then, modulus of elasticity of stone masonry wall increases from $4400 \mathrm{MPa}$ to $12500 \mathrm{MPa}$. After updating, differences between numerical and experimental frequencies of first and second modes were $0 \%$ and $4 \%$, respectively. Calibrated and non-calibrated first two numerical and experimental natural frequency values of minaret are presented in Table 4. After First two mode shapes of minaret were obtained from numerical and experimental analyses as shown in Fig. 8. As results of calibrating 


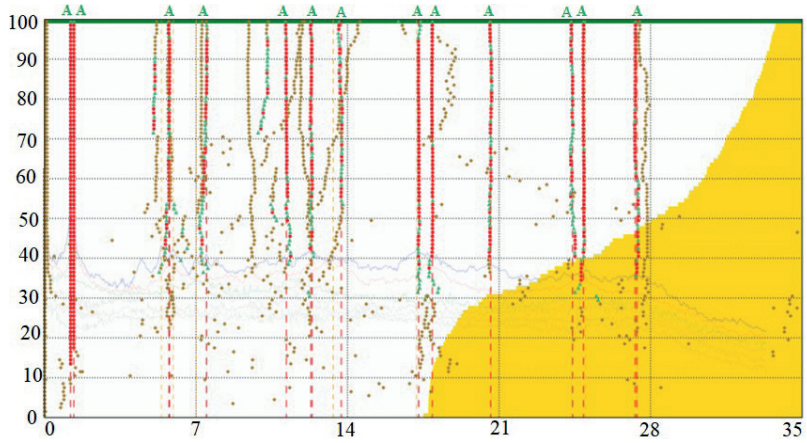

Fig. 7 Stabilization diagram of estimated state space models obtained from the SSI technique

Table 3 The experimental dynamic characteristics

\begin{tabular}{lcc}
\hline Mod & 1 & 2 \\
\hline Frequencies $(\mathrm{Hz})$ & 1.211 & 1.221 \\
\hline
\end{tabular}

process, it was observed that numerical and experimental results were quite close to each other's. Besides, the mode shapes obtained from the initial and calibrated FE models were in the same directions as shown in Fig. 8.

\section{Seismic damage pattern estimation of the minaret}

Linear and non-linear linear seismic analysis of minaret was performed by Abaqus V10 software. Dracker-Prager, Mohr-Coulomb and Concrete Damage Plasticity (CDP) material modeling methods are frequently used to determine the seismic damage ratio in masonry structures. In this study, CDP modeling approach was used to define the nonlinear behavior of the materials forming the masonry units. Although CDP model proposed by Lubliner et al. [27], is used for concrete material, it is later adapted masonry material behavior by Lee and Fenves [28]. In the literature, there are many studies using CDP material model for modeling structural behavior of masonry structures [29-31].

CDP characterizes the behavior of the concrete subjected to tension and compression stresses and the damage parameters as shown in Fig. 9. The material behavior under tensile and compression stresses is linear elastic up to maximum stress. In the case of exceeding of maximum tensile stress, micro cracks in the material occur. When material reaches maximum compression stress, failure

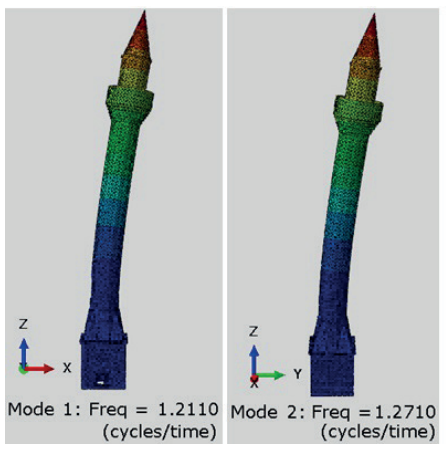

(a)
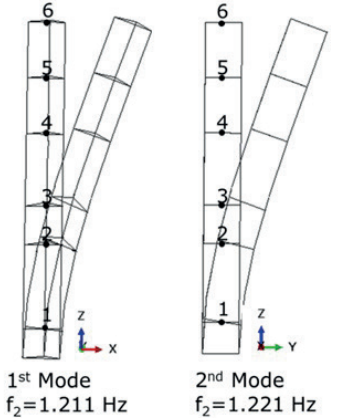

(b)
Fig. 8 The first two updated and experimental mode shapes a) Updated mode shapes; b) Experimental mode shapes
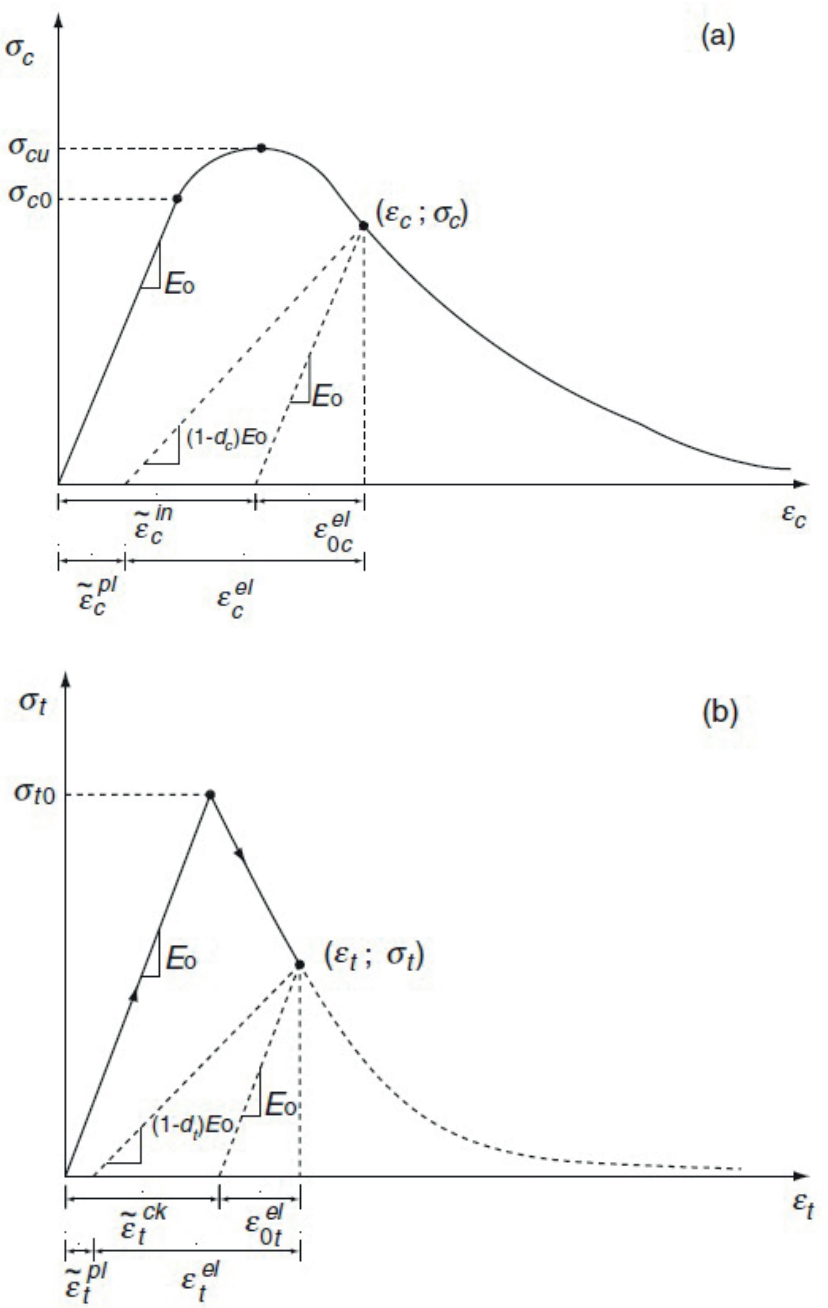

Fig. 9 Damage plasticity stress-strain diagrams (a) uniaxial compression and (b) uniaxial tension

Table 4 The dynamic characteristics obtained before and after the FEM calibration

\begin{tabular}{|c|c|c|c|c|c|}
\hline \multirow[t]{2}{*}{ Mode } & \multicolumn{2}{|c|}{ Numerical frequencies FEM (Hz) } & \multirow{2}{*}{$\frac{\text { Experimental frequencies OMA }(\mathrm{Hz})}{\text { SSI }}$} & \multicolumn{2}{|c|}{ Maximum difference between frequencies $(\%)$} \\
\hline & Before calibration & After calibration & & Before calibration & After calibration \\
\hline 1 & 0.582 & 1.211 & 1.211 & -52 & 0 \\
\hline 2 & 0.613 & 1.271 & 1.221 & -50 & 4 \\
\hline
\end{tabular}


occurs. After exceeding the maximum tensile stress, stiffening in terms of stress and softening in terms of strain occur. After maximum compression stress, the microcracks transform into macro cracks with the softening of the stress-strain behavior.

The damage in terms of tension $\left(\sigma_{t o}\right)$ and compression $\left(\sigma_{c u}\right)$ are defined via the below mathematical relationship (Eqs. (1-2)).

$$
\begin{aligned}
& \sigma_{\text {to }}=\left(1-d_{t}\right) E_{0}\left(\varepsilon_{t}-\varepsilon_{t}^{p l}\right), \\
& \sigma_{c u}=\left(1-d_{c}\right) E_{0}\left(\varepsilon_{c}-\varepsilon_{c}^{p l}\right),
\end{aligned}
$$

where; $E_{0}$ is initial modulus of elasticity, $\sigma_{c}\left(\sigma_{t}\right)$ is uniaxial compressive (tensile) stress, $\varepsilon_{c}\left(\varepsilon_{t}\right)$ is the total strain in compressive and tensile conditions, $\varepsilon_{c}^{p l}\left(\varepsilon_{t}^{p l}\right)$ is the equivalent plastic strain in compressive and tensile conditions, and $d_{c}\left(d_{t}\right)$ is the damage parameters.

In the CDP model, in addition to defining stress strain relationship, four basic material parameters are required to accurately simulate nonlinear behavior. These parameters are obtained from study prepared by Valente and Milani [32] (in Table 5).

In the finite element model calibration, the masonry brick wall elasticity modulus was determined as 4400 MPa. The new compressive strength for masonry brick wall was determined as 4.4 MPa by using Eq. (3) [33] and tensile strength was determined by taking $10 \%$ of compressive strength. Tensile strength for masonry brick wall was determined as $0.44 \mathrm{MPa}$.

$E_{m}=1000 f_{c m}$,

where $E_{m}$ and $f_{c m}$, masonry wall represents the elasticity modulus and compressive strength, respectively. The stress-strain graphs of the masonry brick wall were adopted from the study by Kaushik et al. [34] (Fig. 10).

Turkey and Afyon earthquake risk maps are shown in Fig. 11 [36-38]. Alaca minaret is located in the center of Bolvadin district of Afyon. It can also be seen from Fig. 11 that Afyon city is in earthquake risk situation. The Sultandağ fault passes through Çay district, which is approximately $15 \mathrm{~km}$ away from Bolvadin district.

Table 5 Material Parameters for Masonry in CDP Model [32]

\begin{tabular}{lccc}
\hline Dilation angle & Eccentricity & $\sigma_{b o} / \sigma_{c o}$ & $\mathrm{~K}$ \\
\hline 100 & 0.1 & 1.16 & 0.666 \\
\hline
\end{tabular}
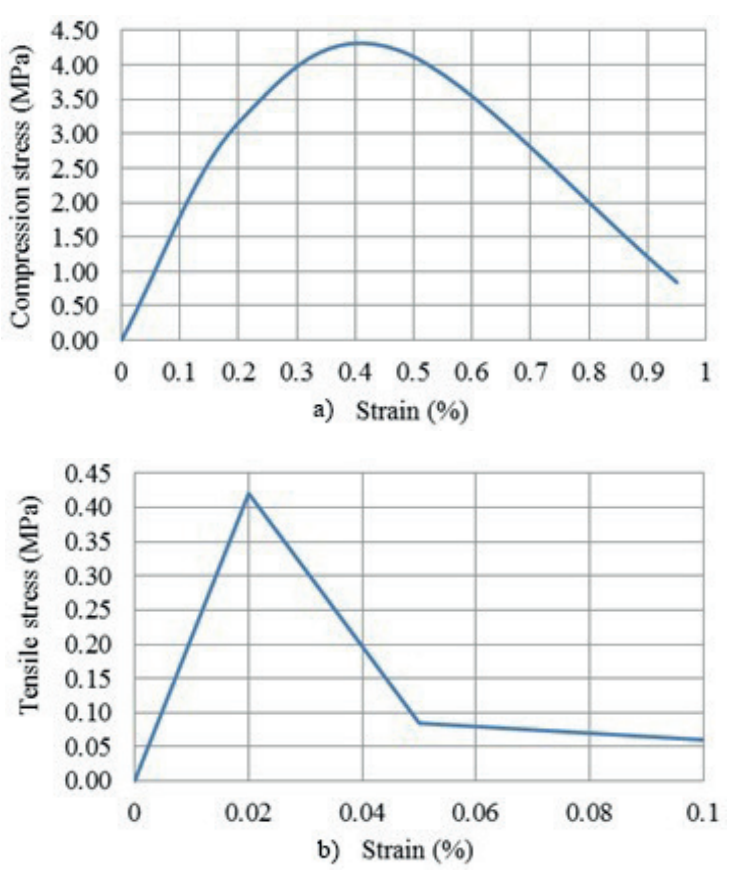

Fig. 10 Stress-strain relationship for brick masonry (a) Compression stress, (b) Tensile stress
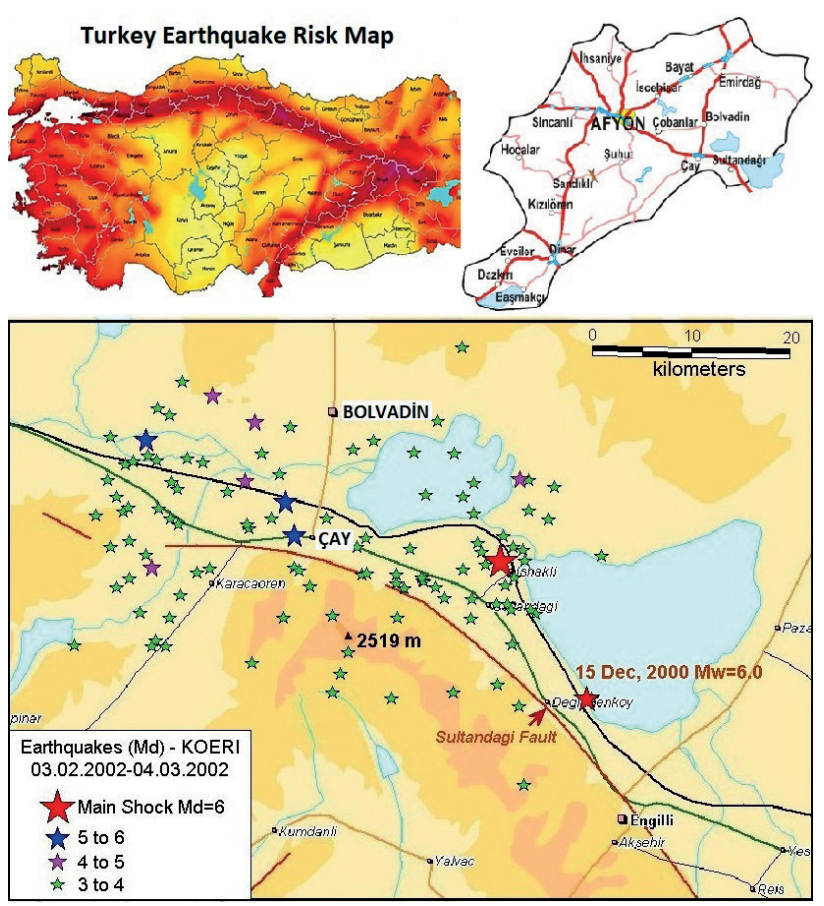

Fig. 11 Turkey earthquake risk map and Sultandağ fault [35-37]

In the Linear Time History (LTH) and Non-linear Time History (NLTH) analyses, acceleration records of Çay earthquake (Mw 6.0) take placed on 3 February 2002 and Dinar earthquake (Mw 6.0) take placed on 10 January 1995 were used. 
The acceleration records implement to finite element model in $\mathrm{x}$ and $\mathrm{y}$ directions. By considering frequency value of the mass participation ratio exceeding $90 \%$ and first frequency value in the modal analyses, material damping ratios ( $a$ and $b$ ) used in the LTH and NLTH analyzes were determined as 2.452 and 0.0001 , respectively. The structural damping ratio was used as 0.05 . Material nonlinearity in Abaqus is treated using the Full Newton-Raphson method [38]. In this study, the Full Newton-Raphson method was used for the minaret analysis. The acceleration records of the earthquakes are present in Fig. 12.

\subsection{LTH analysis of Alaca minaret subjected to Çay and Dinar earthquakes}

As a result of LTH analyses with Çay earthquake, the maximum horizontal displacements at peak point of the minaret were $6.2 \mathrm{~cm}$ and $9.1 \mathrm{~cm}$ in X (U1) and Y (U2) directions, respectively (Fig. 12). With Dinar earthquake, these values were obtained as $23 \mathrm{~cm}$ and $7 \mathrm{~cm}$ in $X$ (U1) and Y (U2) directions, respectively (Fig. 13). Change of horizontal displacement along the minaret height for both earthquakes is presented in Fig. 14.

The maximum principal (tensile) stresses occurring in the masonry minaret subjected to Çay earthquake concentrated around the gate and minimum (compression) stresses concentrated on the wall opposite the door (Fig. 15). It was found that the tensile stress value was $4.52 \mathrm{MPa}$ and limit tensile strength $(0.421 \mathrm{MPa})$ of masonry wall was exceeded approximately 10 times. However, the limit tensile strength was exceeded in only a few mesh elements. The minimum
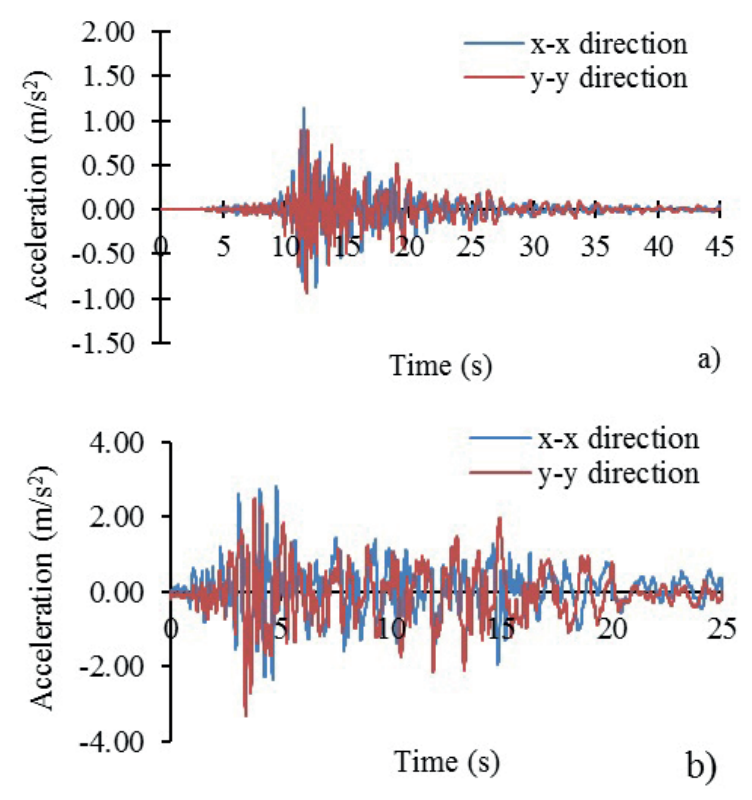

Fig. 12 (a) Çay, (b) Dinar earthquake acceleration records

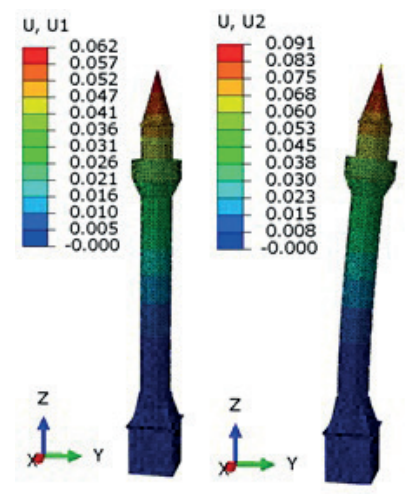

(a)

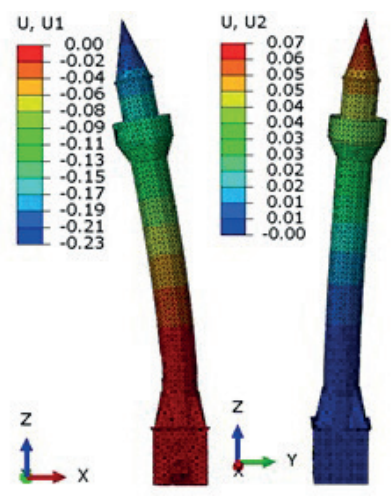

(b)
Fig. 13 Maximum displacement contour shapes under the earthquakes (Units in meter) a) Çay earthquake b) Dinar earthquake

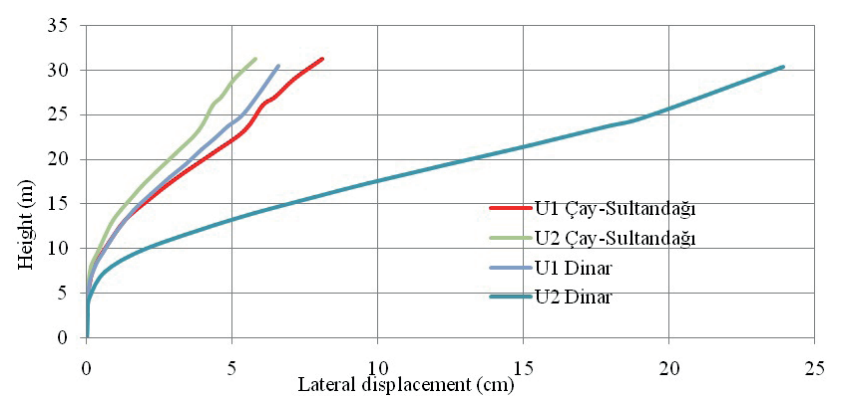

Fig. 14 Lateral displacements obtained throughout the height as a result of the linear analyses

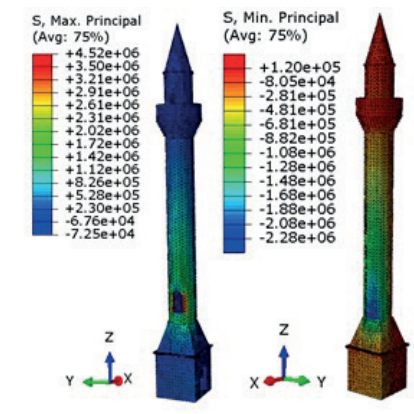

(a)

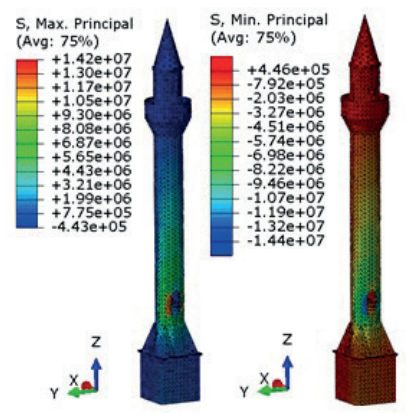

(b)
Fig. 15 Maximum and minimum principal stresses contour under the earthquakes, (a) Çay earthquake, (b) Dinar earthquake

stress value was calculated as $2.28 \mathrm{MPa}$ and limit compression strength $(4.21 \mathrm{MPa})$ of the masonry wall wasn't exceeded. The maximum (tensile) and minimum (compression) principal stresses of minaret exposed to Dinar earthquake were determined as 14.2 $\mathrm{MPa}$ and 14.7 $\mathrm{MPa}$, respectively. It was seen that the tensile and compression stresses were 33 times and 3.5 times higher than limit values of masonry wall, respectively. As a result of LTH analysis, it is concluded that Çay earthquake couldn't cause serious damage in minaret. Dinar earthquake could devastate due to the high tensile stresses and damage concentration regions for minaret. 


\subsection{NLTH analysis of Alaca minaret subjected to Çay earthquake}

As a result of NLTH analyses, the time-dependent variation of maximum horizontal displacements in minarets is shown in Fig. 16. It is seen that the maximum displacement is $3.1 \mathrm{~cm}$ in $\mathrm{U} 1$ direction and $5.4 \mathrm{~cm}$ in $\mathrm{U} 2$ direction. Concentration locations of maximum (tensile) and minimum (compression) principal stresses in the minaret are shown in Fig. 17.

The distribution of damage ratios occurred in minaret for different time steps due to compression stresses is shown in Fig. 18.
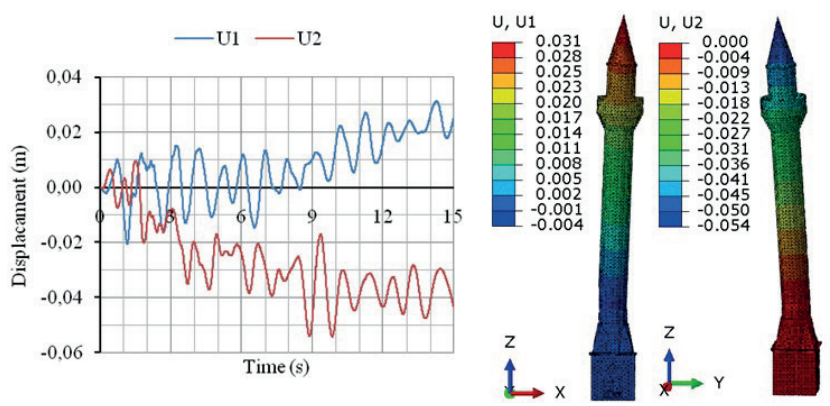

Fig. 16 Time history and contour graphs of displacements in the minaret under Çay earthquake

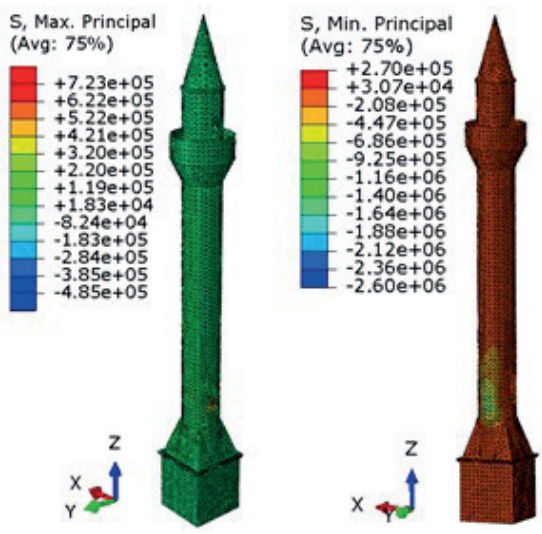

Fig. 17 Maximum and minimum principal stresses in minaret

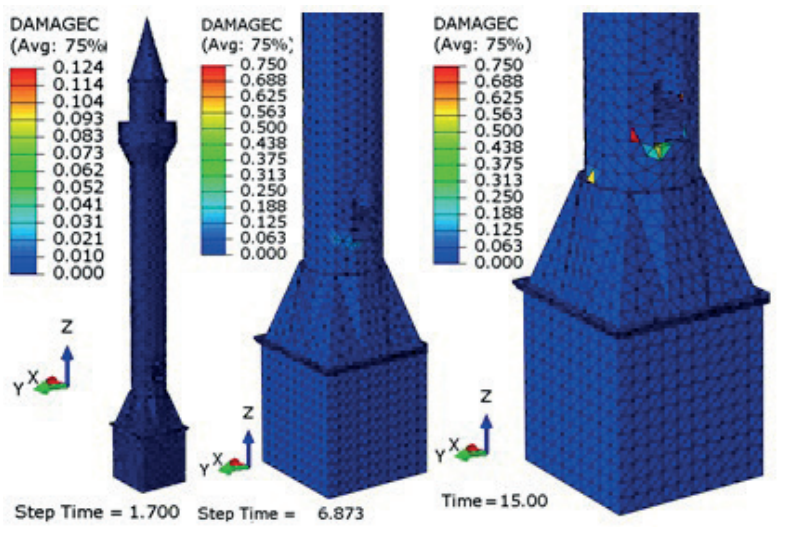

Fig. 18 Compression damage distribution for minaret at different time steps
The damages caused by compression stresses started at $1.7 \mathrm{sec}$ of analysis and increased at certain time steps until the end of the analysis (Fig. 19). At the end of the analysis $(t=15 \mathrm{sec})$, it was determined that limit strain value $(0.004)$ of masonry wall was exceeded (0.019) in only one element and not exceeded the other elements.

Tensile damages caused by tensile stresses are shown in Fig. 20. Tensile damages started at $0.5 \mathrm{sec}$ of analysis. At the end of the analysis, tensile plastic elongations reached to 0.029 (in Fig. 21). Maximum plastic elongation reached

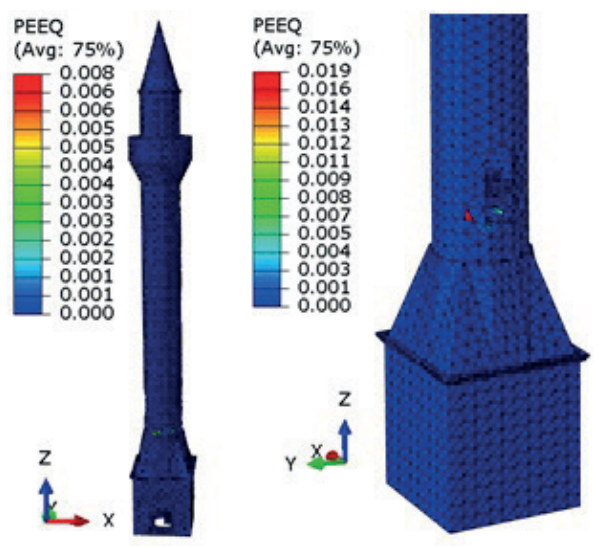

Fig. 19 Compressive plastic strain contour

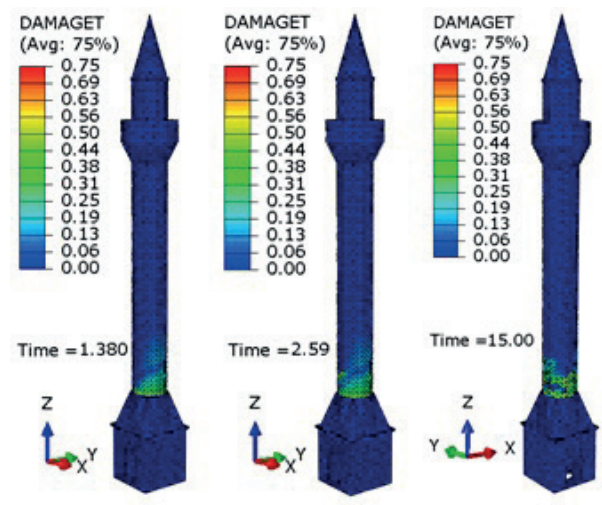

Fig. 20 Tension damage distribution for minaret at different time steps

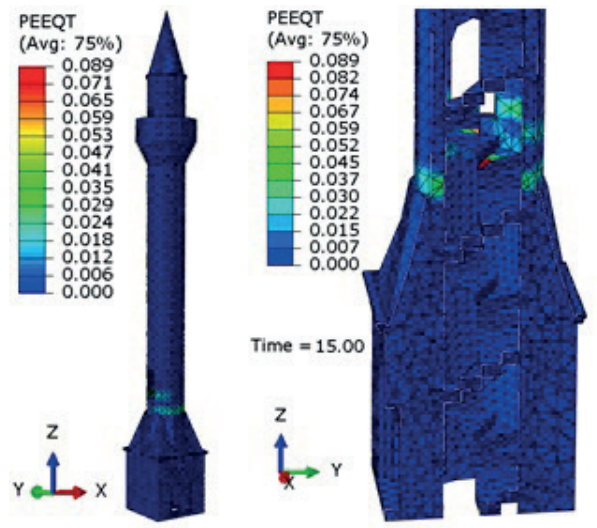

Fig. 21 Tension plastic strain contour 
a value of 0.029 in only one mesh element. As a result of NLTH analyses, it is concluded that minaret subjected to Çay earthquake is safe.

\subsection{NLTH analysis of Alaca minaret subjected to Dinar earthquake}

As a result of NLTH analysis carried out by using the acceleration records of Dinar earthquake, time-dependent variation of maximum horizontal displacements of minaret is presented in Fig. 22. The maximum horizontal displacements at the peak point of minaret are $18.6 \mathrm{~cm}$ in U1 direction and $12.6 \mathrm{~cm}$ in $\mathrm{U} 2$ direction.

The distribution on minaret of the maximum and minimum principal stresses is presented in Fig. 23. In addition, distribution of compression damage ratios caused by compression stresses on the minaret is presented in Fig. 24.

Compression damages occurring in the elements and time-dependent variation is presented in Fig. 24. It is seen in Fig. 25 that the compression damage started at $3.6 \mathrm{sec}$ and the maximum plastic strain reached 0.02 at the end of the analysis. It was seen that the maximum plastic strain value exceeded the limit plastic strain (0.004) in only a few elements. It is concluded that the structure is safe against the stresses in the effect of the Dinar earthquake.
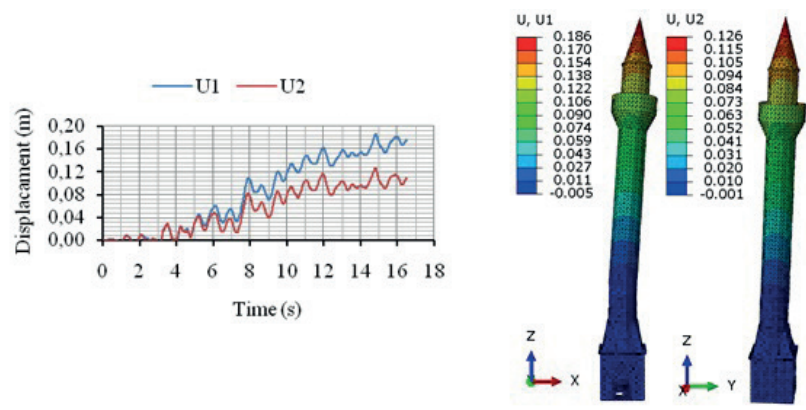

Fig. 22 Time history and contour graphs of displacements in the minaret under Dinar earthquake

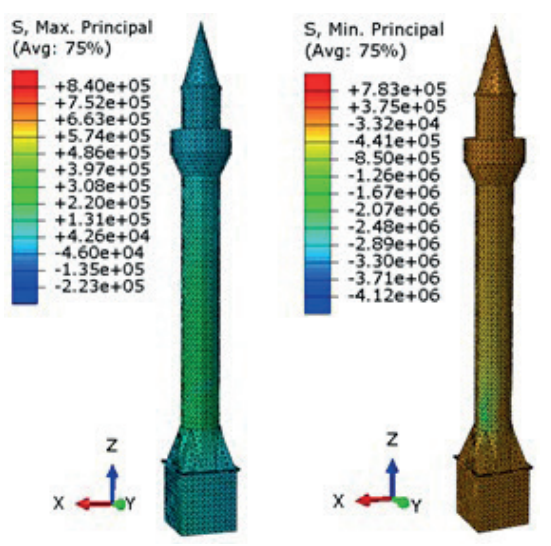

Fig. 23 Maximum and minimum principal stresses in minaret
Tensile damages occurred with NLTH analyses in minaret are presented in Fig. 25. The time-dependent variation of tensile damages is shown in Fig. 25. It was observed that the tensile damage concentrated in the transition zone and cylindrical body and the maximum tensile plastic deformation was 0.02 at the end of the analysis. The elements that exceed limit value of the masonry wall (0.0002) are shown in red color in Figs. 26 and 27. This critical region
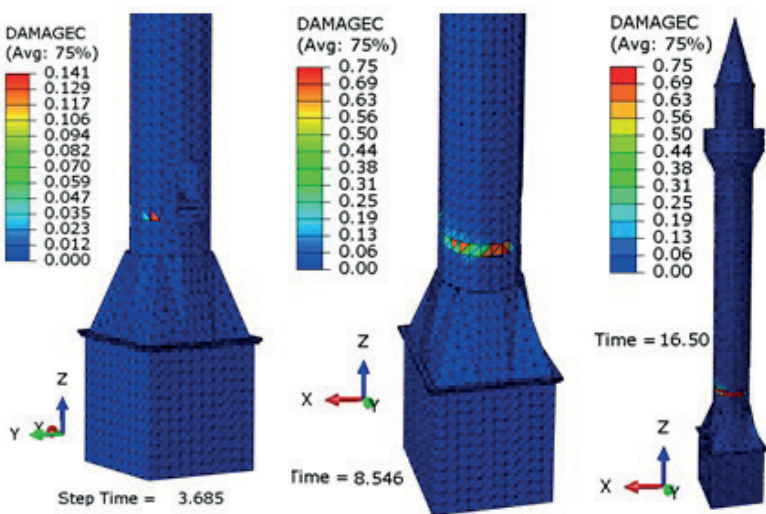

Fig. 24 Compression damage distribution for minaret at different time steps

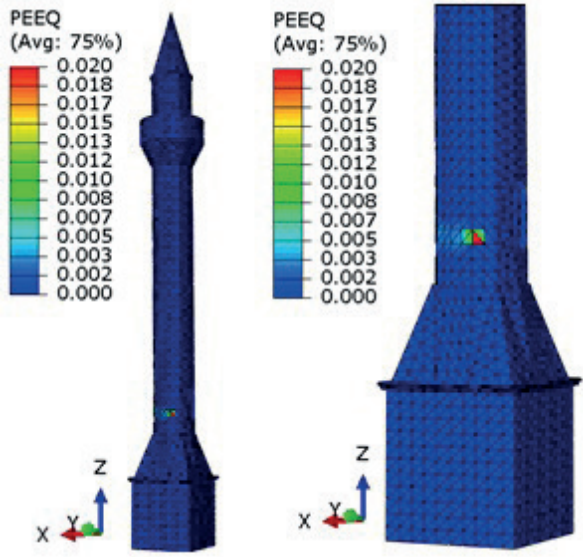

Fig. 25 Compression plastic strain contour
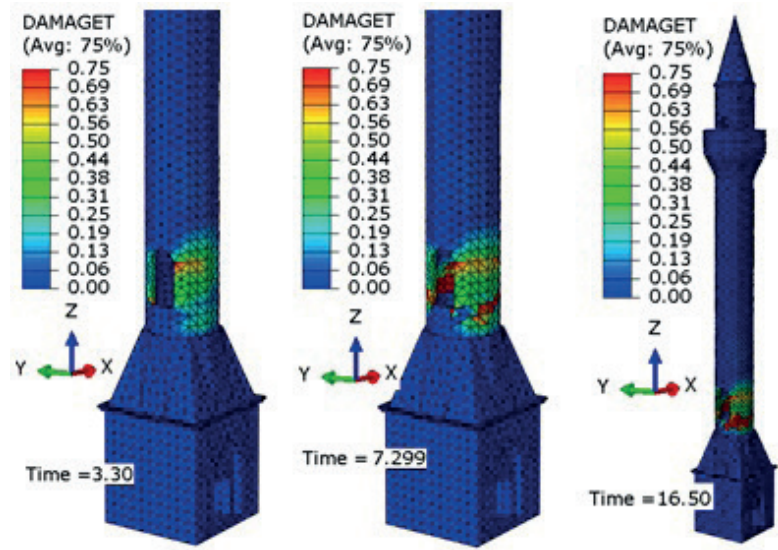

Fig. 26 Tension damage distribution for minaret at different time steps 


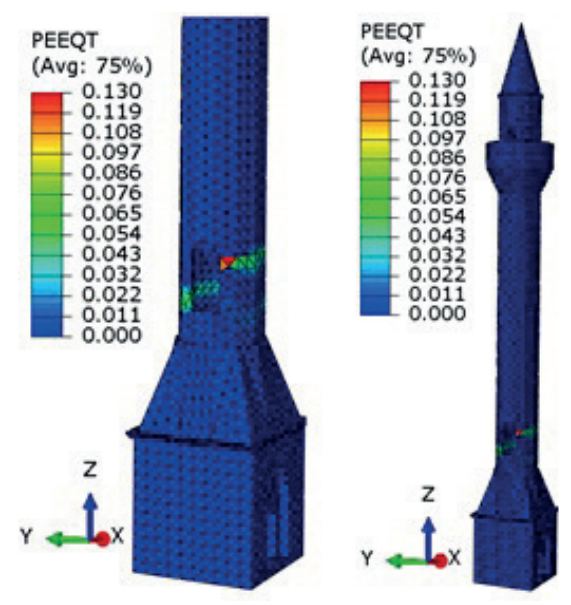

Fig. 27 Tension plastic strain contour

(red element) is limited and the masonry system is not safe under Dinar earthquake. Experienced dramatic events have shown that thin and tall masonry structures like minarets are damaged particularly at the transition segments [39].

\section{Discussions}

LTH and NLTH analyses showed that the tensile and compression stresses eventuated in the same regions of the minaret. However, there were significant differences between the stress values. Therefore, it is concluded that linear analysis methods shouldn't be used in order to determine the seismic behavior of historical masonry structures. In addition, linear analysis methods can be used only in order to determine the regions where the stresses are concentrated. As maximum stresses and plastic strain values obtained from non-linear analyses occur in a few elements, it can be said that the minaret are safe against these earthquakes. However, it is estimated that the minarets can take serious damages from these regions as a results of the more severe earthquakes and special measures for these regions should be taken.

\section{Conclusions}

The aim of this study is to investigate linear and non-linear behaviors and damage ratios of a historical masonry minaret subjected to different seismic loads. FE model representing the realistic behavior of the minaret was calibrated according to the environmental vibration tests. Acceleration records of 1995 Dinar and 2002 Çay earthquakes were used in LTH and NLTH analyses of minaret. The results and evaluations obtained from the study are presented below.

- There is a difference of about $50 \%$ between the numerical frequency values before updating of FE model and the experimental frequency values obtained by the environmental vibration tests.
- Numerical frequency values of the minaret are calibrated according to experimental frequency results and the difference reduced to $4 \%$, thus finite element model is calibrated.

- Both experimental and calibrated mode shapes are in harmony and the first mode shape occur in the $\mathrm{x}$ direction and the second mode shape eventuate in the y direction.

- Maximum principal stresses obtained with linear analysis of minaret subjected to Çay earthquake exceed the limit stress in only a few mesh elements, so minaret isn't seriously damaged under this earthquake.

- Maximum principal stresses obtained with linear analysis of minaret subjected to Dinar earthquake considerably exceed the limit stress. Therefore, it is concluded that minaret may be damaged as a result of Dinar earthquake. However, Alaca minaret wasn't damaged in reality as a result of this earthquake.

- As a result of non-linear analyses, the tensile and compression stresses took place in the minaret subjected to Çay and Dinar earthquakes exceed the limit stresses. Dinar earthquake can cause more plastic deformations formed as a results of tensile stresses.

- It is observed that stresses and plastic deformations concentrate between transition segment and cylindrical body in both earthquakes.

- When the actual damages peculiar to the minarets is investigated in situ, it is thought that the calibrated numerical models successfully reflect the real model.

Seismic behaviors of masonry structures couldn't be actually determined with linear methods, as linear analyses give quite exaggerated results. However, it is observed that stresses obtained with both linear and non-linear analyses concentrate in similar regions of minaret. Therefore, LTH analysis could be used to determine only damage regions of masonry structures subjected to earthquakes. As a result of linear and non-linear analyses carried out with Çay and Dinar earthquakes, Alaca minaret hasn't collapsed just like in reality. However, more severe earthquakes could cause serious damages in Alaca minaret. Finally, seismic evaluations of the historical masonry minarets subjected to earthquakes could safely perform by considering updated FE model and non-linear time history analysis method. 


\section{References}

[1] Cakir, F., Seker, B. S., Durmus, A., Dogangun, A., Uysal, H. "Seismic assessment of a historical masonry mosque by experimental tests and finite element analyses", KSCE Journal of Civil Engineering, 19, pp. 158-164, 2015.

https://doi.org/10.1007/s12205-014-0468-4

[2] Binda, L., Tongini Folli, R., Mirabella Roberti, G. "Survey and Inevstigation for the Diagnosis of Damaged Masonry Structures: the "Torrazzo" of Cremona", In: Proceeding of the 12th International Brick/Block Masonry Conference, Madrid, Spain, 2000, pp. 237-257. [online] Available at: http://www.hms.civil.uminho.pt/ ibmac/2000/237.pdf [Accessed 20 February 2020]

[3] Bayraktar, A., Sevim, B., Altunişik, A. C., Türker, T. "Earthquake analysis of reinorced concrete minarets using ambient vibration test results", Structural Design of Tall and Special Buildings, 19(3), pp. 257-273, 2010.

https://doi.org/10.1002/tal.464

[4] Bayraktar, A., Altunişik, A. C., Sevim, B., Türker, T. "Seismic Response of a Historical Masonry Minaret using a Finite Element Model Updated with Operational Modal Testing", Journal of Vibration and Control, 17(1), pp. 129-149, 2011.

https://doi.org/10.1177/1077546309353288

[5] Tomaszewska, A., Szymczak, C. "Identification of the Vistula Mounting tower model using measured modal data", Engineering Structures, 42, pp. 342-348, 2012.

https://doi.org/10.1016/j.engstruct.2012.04.031

[6] Mortezaei, A., Kheyroddin, A., Ronagh, H. R. "Finite element analysis and seismic rehabilitation of a 1000-year-old heritage listed tall masonry mosque", Structural Design of Tall and Special Buildings, 21(5), pp. 334-353, 2012.

https://doi.org/10.1002/tal.599

[7] D'Ambrisi, A., Mariani, V., Mezzi, M. "Seismic assessment of a historical masonry tower with nonlinear static and dynamic analyses tuned on ambient vibration tests", Engineering Structures, 36, pp. 210-219, 2012.

https://doi.org/10.1016/j.engstruct.2011.12.009

[8] Bartoli, G., Betti, M., Giordano, S. "In situ static and dynamic investigations on the "Torre Grossa" masonry tower", Engineering Structures, 52, pp. 718-733, 2013.

https://doi.org/10.1016/j.engstruct.2013.01.030

[9] Diaferio, M., Foti, D., Gentile, C., Giannoccaro, N. I., Saisi, A. "Dynamic testing of a historical slender building using accelerometers and radar", presented at 6th International Operational Modal Analysis Conference IOMAC' 2015, Gijón, Spain, May, 12-14, 2015. [online] Available at: http://iomac.eu/iomac/2015/pdf/153_ Paper_Gentile.pdf [Accessed 20 February 2020]

[10] Gentile, C., Saisi, A. "Ambient vibration testing of historic masonry towers for structural identification and damage assessment", Construction and Building Materials, 21(6), pp. 1311-1321, 2007. https://doi.org/10.1016/j.conbuildmat.2006.01.007

[11] Doğangün, A., Livaoğlu, R., Acar, R. "A study on seismic behavior of minarets considering soil-structure interaction", In: International Earthquake Symposium Kocaeli 2007, Kocaeli, Turkey, 2007, pp. 393-404. [online] Available at: http://kocaeli2007.kocaeli.edu.tr/ kocaeli2007/TAM_METIN_NUMARALI-SIRALI-PDF/393-404.pdf [Accessed: 20 February 2020]
[12] Foti, D., Diaferio, M., Giannoccaro, N. I., Mongelli, M. "Ambient vibration testing, dynamic identification and model updating of a historic tower", NDT \& E International, 47, pp. 88-95, 2012. https://doi.org/10.1016/j.ndteint.2011.11.009

[13] Oliveira, C. S., Çakti, E., Stengel, D., Branco, M. "Minaret behavior under earthquake loading: The case of historical Istanbul", Earthquake Engineering \& Structural Dynamics, 41(1), pp. 19-39, 2012. https://doi.org/10.1002/eqe.1115

[14] Diaferio, M., Foti, D., Giannocaro, N. I. "Non-destructive characterization and identification of the modal parameters of an old masonry tower", In: 2014 IEEE Workshop on Environmental, Energy, and Structural Monitoring Systems Proceedings, Naples, Italy, 2014, pp. 57-62.

https://doi.org/10.1109/EESMS.2014.6923265

[15] Cakir, F., Uysal, H. "Seismic performance of historical masonry clock tower with adjacent walls", Earthquakes and Structures, 7(2), pp. 217-231, 2014.

https://doi.org/10.12989/eas.2014.7.2.217

[16] Bartoli, G., Betti, M., Facchini, L., Marra, A. M., Monchetti, S. "Bayesian model updating of historic masonry towers through dynamic experimental data", Procedia Engineering, 199, pp. 12581263, 2017. https://doi.org/10.1016/j.proeng.2017.09.267

[17] Shakya, M., Varum, H., Vicente, R., Costa, A. "Empirical Formulation for Estimating the Fundamental Frequency of Slender Masonry Structures", International Journal of Architectural Heritage, 10(1), pp. 55-66, 2016. https://doi.org/10.1080/15583058.2014.951796

[18] Foti, D., Diaferio, M., Giannoccaro, N. I., Ivorra, S. "Structural Identification and Numerical Models for Slender Historical Structures", In: Civil and Environmental Engineering: Concepts, Methodologies, Tools, and Applications, IGI Global, Hershey, PA, USA, 2015, pp. 196-222. https://doi.org/10.4018/978-1-4666-9619-8.ch007

[19] Demir, A., Nohutcu, H., Ercan, E., Hokelekli, E., Altintas, G. "Effect of model calibration on seismic behaviour of a historical mosque", Structural Engineering and Mechanics, 60(5), pp. 749-760, 2016. https://doi.org/10.12989/sem.2016.60.5.749

[20] Nohutcu, H., Hokelekli, E., Ercan, E., Demir, A., Altintas, G. "Collapse mechanism estimation of a historical slender minaret", Structural Engineering and Mechanics, 64(5), pp. 653-660, 2017. https://doi.org/10.12989/sem.2017.64.5.653

[21] Altunişik, A. C., Okur, F. Y., Genç, A. F., Günaydin, M., Adanur, S. "Automated Model Updating of Historical Masonry Structures Based on Ambient Vibration Measurements", Journal of Performance of Constructed Facilities, 32(1), 2018. https://doi.org/10.1061/(ASCE)CF.1943-5509.0001108

[22] Nohutcu, H., Demir, A., Ercan, E., Hokelekli, E., Altintas, G. "Investigation of a historic masonry structure by numerical and operational modal analyses", The Structural Design of Tall and Special Buildings, 24(13), pp. 821-834, 2015. https://doi.org/10.1002/tal.1213

[23] Dassault Systems "Abaqus V10", [computer program] Available at: https://www.3ds.com/products-services/simulia/products/abaqus/ [Accessed: 3 June 2019] 
[24] Structural Vibration Solutions A/S "ARTeMISModal" (Pro 3.0), [computer program] Available at: http://www.svibs.com [Accessed: 3 June 2019]

[25] Peeters, B. "System identification and damage detection in civil engineering", PhD Thesis, Katholieke Universiteit Leuven, 2000. (online) Available at: https://imo.libis.be/primo-explore/fulldisplay?docid=LIRIAS1725571\&context=L\&vid=Lirias\&search scope $=$ Lirias $\&$ tab $=$ default_tab\&lang $=$ en_US\& fromSitemap $=1$ [Accessed: 20 February 2020]

[26] Ishac, M. G., Mehanny, S. S. F. "Do mixed pier-to-deck connections alleviate irregularity of seismic response of bridges with unequal height piers?", Bulletin of Earthquake Engineering, 15, pp. 97-121, 2017. https://doi.org/10.1007/s10518-016-9958-8

[27] Lubliner, J., Oliver, J., Oller, S., Oñate, E. "A Plastic-damage model for concrete", International Journal of Solids and Structures, 25(3), pp. 299-326, 1989.

https://doi.org/10.1016/0020-7683(89)90050-4

[28] Lee, J., Fenves, G. L. "A plastic-damage concrete model for earthquake analysis of dams", Earthquake Engineering and Structural Dynamics, 27(9), pp. 937-956, 1998.

https://doi.org/10.1002/(SICI)1096-9845(199809)27:9<937::AIDEQE764>3.0.CO;2-5

[29] Kocaturk, T., Erdogan, Y. S. "Earthquake behavior of M1 minaret of historical Sultan Ahmed Mosque (Blue Mosque)", Structural Engineering and Mechanics, 59(3), pp. 539-558, 2016. https://doi.org/10.12989/sem.2016.59.3.539

[30] Nohutcu, H. "Seismic Failure Pattern Prediction in a Historical Masonry Minaret under Different Earthquakes", Advances in Civil Engineering, 2019, Article ID: 8752465, 2019. https://doi.org/10.1155/2019/8752465

[31] Bayraktar, A., Hökelekli, E., Halifeoğlu, F. M., Mosallam, A., Karadeniz, H. "Vertical strong ground motion effects on seismic damage propagations of historical masonry rectangular minarets", Engineering Failure Analysis, 91, pp. 115-128, 2018. https://doi.org/10.1016/j.engfailanal.2018.04.029
[32] Valente, M., Milani, G. "Non-linear dynamic and static analyses on eight historical masonry towers in the North-East of Italy", Engineering Structures, 114, pp. 241-270, 2016. https://doi.org/10.1016/j.engstruct.2016.02.004

[33] CEN "Eurocode 6: Design of masonry structures", European Committee for Standardization", Brussels, Belgium, 1996.

[34] Kaushik, H. B., Rai, D. C., Jain, S. K. "Stress-Strain Characteristics of Clay Brick Masonry under Uniaxial Compression", Journal of Materials in Civil Engineering, 19(9), pp. 728-739, 2007. https://doi.org/10.1061/(ASCE)0899-1561(2007)19:9(728)

[35] AFAD "Turkey Earthquake Hazard Map" [online] Available at: https://deprem.afad.gov.tr/deprem-tehlike-haritasi [Accessed: 03 November 2019]

[36] afyonkarahisar03"Afyonkarahisar" [online] Available at: https:// afyonkarahisar03.wordpress.com/afyonkarahisar [Accessed: 03 November 2019] (in Turkish)

[37] Erdik, M., Uckan, E., Sesetyan, K., Demircioglu, M. B., Celep, U., Biro, Y. "Feb. 3, 2002 Sultandai (Turkey) Eartquake" Boğaziçi University, Istanbul, Turkey, 2002. [online] Available: http://www. koeri.boun.edu.tr/depremmuh/eqspecials/sultandag/sultandageq. htm [Accessed: 03.11.2019].

[38] Zienkiewicz, O. C., Taylor, R. L., Zhu, J. Z. "The Finite Element Method: Its Basis and Fundamentals", 6th ed., ButterworthHeinemann, Amsterdam, Netherlands, 2005. https://doi.org/10.1016/C2009-0-24909-9

[39] Bayraktar, A., Altunişik, A. C., Muvafik, M. "Damages of minarets during Erciş and Edremit earthquakes, 2011 in Turkey", Smart Structures and Systems, 14(3), pp. 479-499, 2014. https://doi.org/10.12989/sss.2014.14.3.479 